OPEN ACCESS

Volume: 8

Issue: 1

Month: December

Year: 2019

P-ISSN: 2319-961X

E-ISSN: 2582-0192

Received: 10.10.2019

Accepted: 18.11.2019

Published: 01.12.2019

Citation:

Ramabose, K., and

S.Ganesan. "A Study

on Household Sector

Energy Consumption of

Rural and Urban Areas

in Virudhunagar District

of Tamil Nadu." Shanlax

International Journal of

Economics, vol. 8, no. 1, 2019, pp. 21-31.

DOI:

https://doi.org/10.34293/

economics.v8i1.902

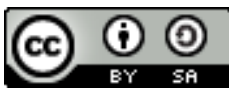

This work is licensed under a Creative Commons Attribution-ShareAlike 4.0 International License

\section{A Study on Household Sector Energy Consumption of Rural and Urban Areas in Virudhunagar District of Tamil Nadu}

\author{
K.Ramabose \\ Ph.D. Research Scholar, Department of Economics \\ Ayya Nadar Janaki Ammal College (A), Sivakasi, Tamil Nadu, India \\ S.Ganesan \\ Associate Professor, Department of Economics, \\ Ayya Nadar Janaki Ammal College (A), Sivakasi, Tamil Nadu, India
}

\begin{abstract}
The word "Energy" is derived from the Greek word 'energeia', which means in work'. It is the power or capacity to do work. Energy has become an important and one of the basic infrastructures for human development and economic growth of a country. Energy is the universal measure of all kinds of work and its consumption has been increasing worldwide. It has become a basic requirement of today's life. In fact, it is the backbone of present day civilization. Thus, with an increase in the living standard of human beings, the energy consumption is also accelerated. There is a strong correlation between standard of living and energy consumption. Any physical activity in this world, whether carried out by human beings or by nature, is caused due to the flow of energy in one form or the other? Energy is required to do any kind of work. The work output depends on the energy input. The capacity to do work depends upon the amount of energy one can control and utilise.
\end{abstract}

Keywords: Energy, GDP, Panchayats, IAYS, CMSPGH.

\section{Introduction}

The word "Energy" is derived from the Greek word 'energeia,' which means 'in work.' It is the power or capacity to do work. Energy has become an important and one of the basic infrastructures for human development and economic growth of a country. Energy is the universal measure of all kinds of work, and its consumption has been increasing worldwide. It has become a basic requirement of today's life. It is the backbone of present-day civilization. Thus, with an increase in the living standard of human beings, the energy consumption is also accelerated. There is a strong correlation between standard of living and energy consumption. Any physical activity in this world, whether carried out by human beings or by nature, is caused due to the flow of energy in one form or the other? Energy is required to do any kind of work. The work output depends on the energy input. The capacity to do work depends upon the amount of energy one can control and utilize. Consumption of a large amount of energy in a country implies better comfort at home due to the use of various home appliances, better transport facilities, and more agricultural and industrial production. All this led to a better quality of life for the people of a country. Therefore, the higher per capita energy consumption means a higher per capita Gross Domestic Product (GDP). That is, energy is regarded as a GDP multiplier. Therefore, the per capita energy consumption of a country is an index of the standard of living or prosperity of the people of that country. 
India is the second-largest commercial energy consumer in Non- OCED East Asia, comprising 19 percent of the total primary energy consumption. Indian economic growth has been associated with increased energy consumption.

Before the industrial revolution, people were essentially depended upon manual and animal power. Life was simple and unsophisticated. The invention of the steam engine by James Watt of Scotland in the year 1785 brought out the industrial revolution, and it was the beginning of a mechanical age or the age of machines. The advent of the internal combustion engine led to further momentum in the use of machines. In the year 1888, Nickola Tesla invented the commercial induction motor. The introduction of electrical machines, along with the commercial availability of electrical power, started the new electrical age. All this led to an increase in energy requirements. But now, due to the introduction of electrical machines along with electrical power, the new electrical age started. This led to an increase in the energy requirement by leaps and bounds.

The energy is one of the key factors in the supply of food and also physical comforts necessary for the existence of mankind. The human and animal energy is depended on the food that they consume. For example, an apple has energy. If a person eats an apple, it will enable him to do work. But to purchase an apple he has to pay money, for which he has to do some work which requires energy. Therefore, the use of energy is an inseparable part of human existence. The energy consumption of a country can be broadly divided into four sectors like domestic, transportation, agriculture, and industrial sectors. The present study pertains to the household sector. In rural areas of developing countries like India, a huge variety of energy consumption patterns are found in the household sector. Households use energy for many purposes. The amount of energy consumption and the types of energy sources depend on many factors like the income of the family and the availability of energy sources. Therefore, the analysis of household energy must be rooted in a sensitive approach not only to the supply of energy but also to the demand for energy. In many developing countries, 90 percent to 100 percent of poor families consume energy for cooking. Most families rely on the cooking fire, and some use candles and torch to meet all their lighting needs. Kerosene is the next most widely used lighting energy source. The amount of energy required for cooking depends on many factors such as the type of food cooked, the quantity of food cooked, the size of the family, energy source, cooking equipment used, and cooking devices.

\section{Review of Literature}

Dhulasi Birrundha, V. and Subburaj, S., have undertaken a study on "Energy consumption pattern of small scale industries in Dindigul Taluk, Anna District." Murugan, M., has made a study on "An analysis of rural household energy consumption in Kanyakumari District - Tamil Nadu." Kuldeep, K. and Amandeep, K., have conducted a study on "Electricity consumption and economic development- Interrelationship in Punjab."

\section{Statement of the Problem}

The electricity is a key element in modern day life. The electricity does all the works right from powering industries and running irrigation pumps to charging mobile phones. Next to the industrial sector, the household sector is consuming a huge amount of energy for household activities in general and in the study area in particular.

In recent years energy has acquired significant importance due to its escalating prices and projected scarcity. The increasing scarcity of fuels poses a serious threat in both rural and urban households. Most of the households have framed their current life around the erroneous notion that energy resource is abundant and expensive. They are not aware of the seriousness of the fact that the natural resources are scarce and shirking fast and how this would affect their life style in the future.

Very few households are conscious of the efforts of over consumption of energy on the limited natural energy reserve. The pricing policy of energy resources itself had been an incentive for households to consume more energy and be carless in their energy consumption behavior. The reason for using up so much energy in the process of economic growth and development might not only be the demand for goods, services, and transportation, but also the strikingly inefficient means using these. 
The household is dependent on a continuous flow of energy from the environment to perform innumerable activities. Life activities are energy-intensive rather than labor-intensive. To meet this great demand requires implementing plans for the development of the energy sector, discovering new techniques of energy production to replace the fast depicting energy sources, and minimization of wastage of energy. Hence, a modest attempt has been made to analyze the household sector energy consumption of rural and urban areas in Virudhunagar District of Tamil Nadu.

\section{Objectives of the Study}

- To identify the energy consumption behavior of rural and urban households in the study area.

- To find the various energy sources in the study area.

- To analyze the factors determining energy consumption in the study area,

\section{Sampling Design}

Virudhunagar District consists of 11 blocks. Out of this 11, 7 blocks are having rural and urban, and the remaining four blocks are having only rural. By naming the Seven blocks are Aruppukottai, Virudhunagar, Rajapalayam, Srivilliputhur, Sivakasi, Vembakkottai, and Sattur. By naming the rural blocks, Kariyapatti, Tiruchuli, Narikudi, and Watrap.

\section{Selection of Blocks}

Based on the District Human Development Index 2017, among urban blocks, the researcher has selected two blocks based on best and worst performance. The best performing block is Sivakasi, and the worst-performing blocks are Vembakkottai. In the same manner, the researcher has selected on the block from the rural, i.e., Tiruchuli. Totally three blocks were selected for the study.

\section{Selection of Panchayats}

Total panchayats in the selected three blocks are 142. Out of this, 132 are rural panchayats. The remaining 10 are urban panchayats. The researcher intended to select 15 panchayats totally, ie., 12 from rural and three from urban by adopting a systematic sampling technique.
The selected urban panchayats are Pallapatti and Viswanatham in Sivakasi blocks. The selected rural panchayats are Kothaneri, Nedungulam, Tachchakkudi, and Zameen Salvarpatti in Sivakasi block,Kangarseval,Nadhikkudi,Subramaniyapuram, and Vijayarengapuram in Vembakkottai block, Kullampatti, Pannaimoondradaippu, Sennilaikkudi, and Vidathakulam in Tiruchuli block.

\section{Sample Selection}

From each rural panchayat, the researcher intended to select 25 households as sample households. Accordingly, 300 sample households are selected and included in the study by adopting a simple random sampling technique. From each urban panchayats, 50 households are selected, totally 150 households included. Hence, the total sample size in 450 .

\section{Tools of Analysis}

The tools used to analyze the data are percentages, correlation, and chi-square tests.

\section{Classification of the Respondents Basis on Type of House}

To examine the level of energy consumption and conservation behavior, it is important to know the type of dwellings in which the respondents live and the latent of facilities available at home. The distribution of the respondents according to the type of house is indicated in Table 1.

Table 1 Classification of The Respondents Basis on Type of House

\begin{tabular}{|c|c|c|c|c|}
\hline $\begin{array}{l}\text { S. } \\
\text { No. }\end{array}$ & $\begin{array}{l}\text { Type of } \\
\text { House }\end{array}$ & Rural & Urban & Total \\
\hline 1. & Hut & $23(7.67)$ & $12(8.00)$ & 35 \\
\hline 2. & Tiled House & $112(37.33)$ & $28(18.67)$ & 140 \\
\hline 3. & $\begin{array}{l}\text { Concrete } \\
\text { House }\end{array}$ & $126(42.00)$ & $76(50.67)$ & 202 \\
\hline 4. & $\begin{array}{l}\text { Storied } \\
\text { House }\end{array}$ & $39(13.00)$ & $34(22.67)$ & 73 \\
\hline \multicolumn{2}{|r|}{ Total } & $300(100)$ & 150 (100) & 450 \\
\hline
\end{tabular}

Source: Survey Data

Note: The figures within brackets show percentages.

According to Table 1, out of a total of 450 respondents, 35, 140, 202, and 73 live in huts, 
tiled houses, concrete houses, and storied houses, respectively. Out of 300 rural respondents, 23 (7.67 percent), 112 (37.33 percent), 126 (42.00 percent), and 39 (13.00 percent) live in huts, tiled houses, concrete houses, and storied houses respectively. Out of 150 urban respondents, 12 (8.00 percent), 28 (18,67per cent), 76 (50.67 percent), and 34 (22.67 percent) live in huts, tiled houses, concrete houses, and storied houses respectively. These data confirm that a majority of the respondents have concrete houses. This may be due to the free housing schemes of the Central and State Governments like Indira Awas Yojana Scheme (IAYS) and Chief Minister's Solar Powered Green House Scheme (CMSPGH).

\section{Classification of the Respondents Basis on ownership of House}

The ownership of the house (owned or rented) is yet another factor that influences energy consumption and energy conservation behavior. In rural areas, the respondents live in huts and thatched houses, while in urban areas, they live in concrete and storied houses. Since energy consumption and conservation behavior may depend upon the ownership of houses, the researcher collected the relevant data and delineated the same in Table 2.

Table 2 Classification of the Respondents Basis on Ownership of House

\begin{tabular}{|c|c|c|c|c|}
\hline $\begin{array}{c}\text { S. } \\
\text { No. }\end{array}$ & $\begin{array}{c}\text { Ownership } \\
\text { of House }\end{array}$ & Rural & Urban & Total \\
\hline 1. & Own House & $\begin{array}{c}246 \\
(82.00)\end{array}$ & $\begin{array}{c}116 \\
(77.33)\end{array}$ & 362 \\
\hline 2. & $\begin{array}{c}\text { Rented } \\
\text { House }\end{array}$ & $\begin{array}{c}54 \\
(18.00)\end{array}$ & $34(22.67)$ & 88 \\
\hline \multicolumn{2}{|c|}{ Total } & $\mathbf{3 0 0}(\mathbf{1 0 0})$ & $\mathbf{1 5 0}(\mathbf{1 0 0})$ & $\mathbf{4 5 0}$ \\
\hline
\end{tabular}

Source: Survey Data

Note: The figures within the brackets show percentages

Table 2 reveals that out of the total 450 respondents, 362 live in owned houses, and 88 in a rented house. Out of 300 rural respondents, 246 (82 percent) live in owned houses and the remaining 54 (18 percent) in a rented house. Out of 150 urban respondents, 116 (77.33 percent) live in owned houses and the remaining 34 (22.67 percent) in a rented house. It shows that a majority of the rural, as well as urban respondents, possess their own houses. This is also due to free housing schemes by the governments.

\section{Classification of the Respondents Basis on Occupation}

The occupation of the respondent is one more important factor that influences energy consumption and conservation behavior. The occupation-wise classification of the respondents is depicted in Table 3.

Table 3 Classification of the Respondents Based on Occupation

\begin{tabular}{|c|l|c|c|c|}
\hline $\begin{array}{c}\text { S. } \\
\text { No. }\end{array}$ & $\begin{array}{l}\text { Occupation } \\
\text { of the } \\
\text { Respondent }\end{array}$ & Rural & Urban & Total \\
\hline 1. & $\begin{array}{l}\text { Government } \\
\text { Employees }\end{array}$ & $\begin{array}{c}37 \\
(12.33)\end{array}$ & $\begin{array}{c}34 \\
(22.67)\end{array}$ & 71 \\
\hline 2. & $\begin{array}{l}\text { Private } \\
\text { Employees }\end{array}$ & $\begin{array}{c}100 \\
(33.33)\end{array}$ & $\begin{array}{c}60 \\
(40.00)\end{array}$ & 160 \\
\hline 3. & $\begin{array}{l}\text { Agriculture } \\
\text { Labourers }\end{array}$ & $\begin{array}{c}56 \\
(18.67)\end{array}$ & $\begin{array}{c}8 \\
(5.33)\end{array}$ & 64 \\
\hline 4. & Business men & $\begin{array}{c}50 \\
(16.67)\end{array}$ & $\begin{array}{c}20 \\
(13.33)\end{array}$ & 70 \\
\hline 5. & $\begin{array}{l}\text { Contract } \\
\text { Workers }\end{array}$ & $\begin{array}{c}42 \\
(14.00)\end{array}$ & $\begin{array}{c}19 \\
(12.67)\end{array}$ & 61 \\
\hline 6. & Others & $15(5.00)$ & $9(6.00)$ & 24 \\
\hline \multicolumn{2}{|c|}{ Total } & $\mathbf{3 0 0}(\mathbf{1 0 0})$ & $\mathbf{1 5 0}(\mathbf{1 0 0})$ & $\mathbf{4 5 0}$ \\
\hline
\end{tabular}

Source: Survey Data

Note: The figures within the brackets show percentages

Table 3 infers that out of the total 450 respondents, 71, 160, 64, 70, 61, and 24 are government employees, private employees, agricultural laborers, businessmen, contract workers, and other workers, respectively. Out of 300 rural respondents, 37 (12. 33 percent), 100 (33.33 percent), 56 (18.67 percent), 50 (16.67), 12 (14.00 percent) and 15 (5.00 percent) are government employees, private employees, agricultural labourers, businessmen, contract workers and other workers respectively. Out of 150 urban respondents, 34 (22.67 percent), 60 (40.00 percent), 8 (5.33 percent), 20 (13.33 percent), 19 (12.67 percent) and 9 (6.00 percent) are government employees, private employees, agricultural labourers, businessmen, contract workers and other workers respectively. 
Classification of the Respondents Basis on Annual Family Income

The standard of living depends upon the income of the family. Generally, if the standard of living of the family is high, the consumption of electricity is also high and vice versa. Hence, the researcher collected the data regarding the annual income of the family and presented the same in Table 4.

Table 4 Classification of the Respondents Basis on Annual Family Income

\begin{tabular}{|c|c|c|c|c|}
\hline \multirow{2}{*}{$\begin{array}{l}\text { S. } \\
\text { No. }\end{array}$} & \multirow{2}{*}{$\begin{array}{l}\text { Annual } \\
\text { income } \\
\text { (in Rs.) }\end{array}$} & \multicolumn{3}{|c|}{ Number of Respondents } \\
\hline & & Rural & Urban & Total \\
\hline 1. & $\begin{array}{l}\text { Below } \\
15,000\end{array}$ & $\begin{array}{c}66 \\
(22.00)\end{array}$ & $\begin{array}{c}30 \\
(20.00)\end{array}$ & $\begin{array}{c}96 \\
(21.33)\end{array}$ \\
\hline 2. & $\begin{array}{l}15,001- \\
30,000\end{array}$ & $\begin{array}{c}167 \\
(55.67)\end{array}$ & $\begin{array}{c}65 \\
(43.33)\end{array}$ & $\begin{array}{c}232 \\
(51.56)\end{array}$ \\
\hline 3. & $\begin{array}{l}30,001- \\
45,000\end{array}$ & $\begin{array}{c}50 \\
(16.67)\end{array}$ & $\begin{array}{c}26 \\
(17.33)\end{array}$ & $\begin{array}{c}76 \\
(16.89)\end{array}$ \\
\hline 4. & $\begin{array}{l}45,001- \\
60,000\end{array}$ & $\begin{array}{c}11 \\
(3.67)\end{array}$ & $\begin{array}{c}12 \\
(8.00)\end{array}$ & $\begin{array}{c}23 \\
(5.11)\end{array}$ \\
\hline 5. & $\begin{array}{l}\text { Above } \\
60,000\end{array}$ & $\begin{array}{c}6 \\
(2.00)\end{array}$ & $\begin{array}{c}17 \\
(11.33)\end{array}$ & $\begin{array}{c}23 \\
(5.11)\end{array}$ \\
\hline \multicolumn{2}{|c|}{ Total } & $300(100)$ & $150(100)$ & 450 \\
\hline
\end{tabular}

Source: Survey Data

Note: The figures within brackets show a percentage

It is obvious from Table 4 that out of 300 rural families, 66 (22.00 percent) belong to the annual family income below Rs.15, 000, and 167 (55.67 percent) come under the income range of Rs.15, 001 to Rs.30, 000. About 50 (16.67 percent) belong to the income range between Rs. 30,001, and Rs. 45,000. Remaining 11 (3.67 percent) and 6 (2.00 percent) fall under the income range of Rs. 45,001 to Rs. 60,000 and above Rs. 60,000 . Out of 150 urban families, 30 (20.00 percent) have an annual income of less than Rs. 15,000, while 65 (43.33 percent), 26 (17.33 percent), 12 (8.00 percent), and 17 (11.33 percent) families have an annual income between Rs. 15,001, and Rs. 30,000, Rs. 30,001, and Rs. 45,000, Rs. 45,001 and Rs.60,000 and above Rs.60,000.

\section{Classification of the Respondents Basis on Family Size}

The size of the family is also an important factor that determines the energy consumption and conservation behavior of the households. Hence, the researcher collected the data and depicted the same in Table 5.

Table 5 Classification of the Respondents Basis on Family Size

\begin{tabular}{|c|l|c|c|c|c|}
\hline \multirow{2}{*}{$\begin{array}{c}\text { S. } \\
\text { No. }\end{array}$} & \multirow{2}{*}{ Area } & \multicolumn{2}{|c|}{ Number of Family Members } & \multirow{2}{*}{ Total } \\
\cline { 3 - 5 } & Below 3 & $\mathbf{3 - 6}$ & $\begin{array}{c}\text { Above } \\
\mathbf{6}\end{array}$ & \\
\hline 1. & Rural & $\begin{array}{c}54 \\
(18.00)\end{array}$ & $\begin{array}{c}200 \\
(66.67)\end{array}$ & $\begin{array}{c}46 \\
(15.33)\end{array}$ & $\begin{array}{c}300 \\
(100)\end{array}$ \\
\hline 2. & Urban & $\begin{array}{c}25 \\
(16.67)\end{array}$ & $\begin{array}{c}119 \\
(79.33)\end{array}$ & $6(4.33)$ & $\begin{array}{c}150 \\
(100)\end{array}$ \\
\hline \multicolumn{2}{|c|}{ Total } & $\mathbf{7 9}$ & $\mathbf{3 1 9}$ & $\mathbf{5 2}$ & $\mathbf{4 5 0}$ \\
\hline
\end{tabular}

Source: Survey Data

Note: The figures within the brackets show percentages

It is obvious from Table 5 that out of 300 rural families, 200 (66.67 percent) have 3 to 6 members, and the families below three members are 54 (18.00 percent). About 46 (15.33 percent) families have above six members. Out of 150 urban families, 119 (79.33 percent) have 3 to 6 members, and the families below three members are 25 (16.67 percent). The families with more than six members are insignificant, i.e., 6 (4.00 percent). From the Table, we understand that both in rural and urban areas, a majority of 319 families have 3 to 6 members.

\section{Classification of the Respondents Basis on} Number of Rooms in their Houses

The consumption of electricity in the household sector mainly depends upon the number of rooms in the house. The number of rooms is positively related to the consumption of electricity. In this regard, the researcher collected the data and shown in Table 6.

Table 6 Classification of the Respondents Basis on Number of Rooms in their Houses

\begin{tabular}{|c|c|c|c|c|}
\hline \multirow{2}{*}{$\begin{array}{l}\text { S. } \\
\text { No. }\end{array}$} & \multirow{2}{*}{$\begin{array}{c}\text { Number of } \\
\text { Rooms }\end{array}$} & \multicolumn{3}{|c|}{ Number of Households } \\
\hline & & Rural & Urban & Total \\
\hline 1. & $\begin{array}{l}\text { Single } \\
\text { Room }\end{array}$ & $27(9.00)$ & $11(7.33)$ & $\begin{array}{c}38 \\
(8.44)\end{array}$ \\
\hline 2. & Two Rooms & $\begin{array}{c}103 \\
(34.33)\end{array}$ & $\begin{array}{c}42 \\
(28.00)\end{array}$ & $\begin{array}{c}145 \\
(32.22)\end{array}$ \\
\hline 3. & $\begin{array}{l}\text { Three } \\
\text { Rooms }\end{array}$ & $63(21.00)$ & $\begin{array}{c}20 \\
(13.33)\end{array}$ & $\begin{array}{c}83 \\
(18.44)\end{array}$ \\
\hline 4. & Four Rooms & $59(19.67)$ & $\begin{array}{c}31 \\
(20.67)\end{array}$ & $\begin{array}{c}90 \\
(20.00)\end{array}$ \\
\hline
\end{tabular}




\begin{tabular}{|c|l|c|c|c|}
\hline 5. & $\begin{array}{l}\text { Above Four } \\
\text { Rooms }\end{array}$ & $48(16.00)$ & $\begin{array}{c}46 \\
(30.67)\end{array}$ & $\begin{array}{c}94 \\
(20.89)\end{array}$ \\
\hline \multicolumn{2}{|c|}{ Total } & $\mathbf{3 0 0}(\mathbf{1 0 0})$ & $\mathbf{1 5 0}(\mathbf{1 0 0})$ & $\mathbf{4 5 0}$ \\
\hline
\end{tabular}

Source: Survey Data

Note: The figures within the brackets show percentages

It is evident from Table 6 that out of 300 rural houses, 27 ( 9.00 percent) have only one room, while 103(34.33 percent), 63(21.00 percent), 59 (19.67 percent) and 48 (16.00 percent) have two rooms, three rooms, four rooms and above four rooms respectively. Out of 150 urban houses, 11 (7.33 percent) have only one room, while 42 (28 percent), 20(13.33 percent), 31(20.67 percent), and 46 (30.67 percent) have two rooms, three rooms, four rooms and above four rooms respectively. It is concluded that the number of houses in rural areas has more than four rooms. This is because there are several joint families in rural areas.

\section{Classification of the Respondents Basis on Lighting Equipment}

The different types of lighting equipment are used by the respondents. The energy consumption of different lighting equipment is based on the types of lighting equipment like incandescent lamps, tube lights, CFL, and LED bulbs. The CFL and LED bulbs consume less energy than incandescent lamps and tube lights. In this connection, the researcher collected the data regarding the lighting equipment used by the respondents and represented it in Table 7.

Table 7 Classification of the Respondents on the Basis on Lighting Equipment

\begin{tabular}{|c|c|c|c|c|}
\hline $\begin{array}{l}\text { S. } \\
\text { No. }\end{array}$ & Equipment & Rural & Urban & Total \\
\hline 1 & $\begin{array}{l}\text { Incandescent } \\
\text { Lamp }\end{array}$ & $30(10.00)$ & $12(8.00)$ & 42 \\
\hline 2. & Tube Light & $190(63.33)$ & $60(40.00)$ & 250 \\
\hline 3. & CFL & $50(16.67)$ & $34(22.67)$ & 84 \\
\hline 4. & LED & $30(10.00)$ & $44(29.33)$ & 74 \\
\hline & Total & $300(100)$ & $150(100)$ & 450 \\
\hline
\end{tabular}

Source: Survey Data

Note: The figures within the brackets show percentages

It is understood from Table 7 that in rural areas, out of 300 households, 30 (10. 00 percent) use incandescent lamps and tube lights, CFL and LED lamps are used by 190 (63.33 percent), 50 (16.67 percent) and 30 (10.00 percent) households respectively. In urban areas, incandescent lamps, tube lights, CFL, and LED lamps are used by 12 (8.00 percent), 60 (40.00 percent), 34 (22.67 percent), and 44 (29.33 percent) households respectively. Hence, it is observed that even though the CFL and LED lamps are introduced, a majority of the households in both rural and urban areas still use tube lights.

\section{Classification of the Respondents basis on Usage of Households Appliances}

Since the study pertains to energy consumption and conservation behavior in households, it is the responsibility of the researcher to collect the necessary data regarding the household appliances used by the sample households. Hence, the researcher collected the data and presented the same in Table 8 .

Table 8 Classification of the Respondents Basis on Usage of Households Appliances

\begin{tabular}{|c|l|c|c|}
\hline $\begin{array}{c}\text { S. } \\
\text { No. }\end{array}$ & \multicolumn{1}{|c|}{$\begin{array}{c}\text { Household } \\
\text { Appliances }\end{array}$} & Rural & Urban \\
\hline 1 & Ceiling Fan & $254(84.67)$ & $130(86.67)$ \\
\hline 2 & Table Fan & $272(90.67)$ & $138(92.00)$ \\
\hline 3 & T.V & $281(93.67)$ & $143(95.33)$ \\
\hline 4 & Tap Recorder & $33(11.00)$ & $17(11.33)$ \\
\hline 5 & Mixie & $236(78.67)$ & $137(91.33)$ \\
\hline 6 & Grinder & $166(55.33)$ & $108(72.00)$ \\
\hline 7 & Refrigerator & $68(22.67)$ & $66(44.00)$ \\
\hline 8 & Air & $14(4.67)$ & $37(24.67)$ \\
\hline 9 & Wonditioner & $25(8.33)$ & $40(26.67)$ \\
\hline 10 & Iron Box & $69(23.00)$ & $64(42.67)$ \\
\hline 11 & Heater & $12(4.00)$ & $21(14.00)$ \\
\hline 12 & Electric Stove & $37(12.33)$ & $23(15.33)$ \\
\hline 13 & Computer & $6(2.00)$ & $10(6.67)$ \\
\hline 14 & Lap top & $67(22.33)$ & $54(36.00)$ \\
\hline 15 & Motor Pump & $35(11.67)$ & $53(35.33)$ \\
\hline 16 & Mobile Phone & $283(94.33)$ & $146(97.33)$ \\
\hline 17 & UPS & $40(13.33)$ & $33(22.00)$ \\
\hline 18 & Exhaust Fan & $15(5.00)$ & $33(22.00)$ \\
\hline
\end{tabular}

Source: Survey Data

Note: The figures within the brackets show percentages It is inferred from Table 8, that out of 300 rural 
households, the table fans and ceiling fans are used by 254 (84.67 percent) and 272 (90.67 percent) households respectively, whereas in urban areas, out of 150 households, it is 130 (86.67 percent) and 138 (92.00 percent) households respectively. The T.Vs. are used by 281(93.67 percent) rural households, and it is 143 (95.33 percent) for urban households. The tape recorders are used by 33 (11.00 percent) rural households, while in urban areas, it is 17 (11.33). The mixies are used by 236 (78.67 percent) and 137 (91.33 percent) rural households and urban households, respectively. The grinders are used by 166 (55.33 percent) rural households and 108 (72.00 percent) urban households. The refrigerators and air conditioners are used by 68 (22.67 percent) and 14 (4.67 percent) rural households respectively, and urban households it is 66 (44.00 percent) and 37 (24.67 percent), respectively.

About 25 (8.33 percent) and 69 (23.00 percent) rural households used washing machines and iron boxes respectively, whereas, for urban households, it is 40 (26.67 percent) and 64 (42.67 percent), respectively. The heaters and electric stoves are used by 12 (4.00 percent) and 37 (12.33 percent) rural households, respectively, while it is 21 (14.00 percent) and 23 (15.33 percent) respectively for urban households. The computers are used only by 6 (2.00 percent) rural households, but in urban areas, 10 (6.67 percent) households used computers. The lap tops are used by 67 (22.33 percent) rural households, but in urban areas, 54 (36.00 percent) households used lap tops.

The motor pumps and mobile phones are used by 35 (11.67 percent) and 283 (94.33 percent) by rural households, respectively, and 53 (35.33 percent) and 146 (97.33 percent) by urban households respectively. In rural households, the UPSs and exhaust fans are used by 40 (13.33 percent) and 15 (5.00 percent) respondents, respectively, whereas it is 33 (22.00 percent) each for urban households. The table indicates that a large number of households have fans, TVs., mixies, and grinders. This is due to the priceless distribution of fans, T.Vs., mixies, and grinders by the State government

\section{Classification of the Respondents Basis on Fuel Used For Cooking}

The energy consumption in households mainly depends upon the type of fuel used for cooking. Hence, the researcher collected and classified the information regarding the consumption of energy for cooking in the study area, and the same is shown in Table 9.

\section{Table 9 Classification of the Respondents Based} on Fuel Used gor Cooking

\begin{tabular}{|c|l|c|c|c|}
\hline $\begin{array}{c}\text { S. } \\
\text { No. }\end{array}$ & Fuel Type & Rural & Urban & Total \\
\hline 1. & $\begin{array}{l}\text { Fire wood and } \\
\text { Agricultural } \\
\text { Residues }\end{array}$ & $\begin{array}{c}101 \\
(33.67)\end{array}$ & $\begin{array}{c}21 \\
(14.00)\end{array}$ & 122 \\
\hline 2. & Kerosene & $\begin{array}{c}40 \\
(13.33)\end{array}$ & $\begin{array}{c}24 \\
(16.00)\end{array}$ & 64 \\
\hline 3. & LPG & $\begin{array}{c}149 \\
(49.67)\end{array}$ & $\begin{array}{c}100 \\
(66.67)\end{array}$ & 249 \\
\hline 4. & Electricity & $\begin{array}{c}10 \\
(3.33)\end{array}$ & $\begin{array}{c}5 \\
(3.33)\end{array}$ & 15 \\
\hline \multicolumn{7}{|c|}{ Total } & $\begin{array}{c}\mathbf{3 0 0} \\
(\mathbf{1 0 0})\end{array}$ & $\begin{array}{c}\mathbf{1 5 0} \\
\mathbf{( 1 0 0 )}\end{array}$ & $\mathbf{4 5 0}$ \\
\hline
\end{tabular}

Source: Survey Data

Note: The figures within the brackets show percentages

It is evident from Table 9 that in ru ral areas, out of 300 households, 101 (33.67 percent) use fire wood for cooking. About 40 (13.33 percent), 149 (49.67 percent), and 10 (3.33 percent) households use kerosene, LPG and electricity respectively. In urban areas, fire wood and agricultural residues, kerosene, LPG, and electricity are used by 21 (14.00 percent), 24 (16.00 percent), 100 (66.67 percent), and only 5 (3.33 percent) households respectively. Hence, it is concluded that a majority of the households (149 in rural areas and 100 in urban areas) in both rural and urban areas use LPG for cooking. It may be due to the subsidy provided by the government.

\section{Energy Consumption Analysis}

In this paper, there is a modest attempt has been taken to analyze the relationship between energy consumption and the household characteristics of the sample respondents. Further, it was analyzed the factors determining energy consumption. For this, multiple linear regression analysis was used in Table 
10. Quantitative variables such as the total income of the family, the number of rooms in houses, and the number of family members were correlated with energy consumption. The result is given below.

Table 10 Correlation Analysis Between Energy Consumption and Household Character

\begin{tabular}{|c|c|c|c|c|}
\hline \multicolumn{5}{|c|}{ Correlation Matrix } \\
\hline
\end{tabular}

** denotes statistically significant at $1 \%$ level.

It can be interpreted from Table 10 that the household characteristics such as the total income of the family, number of rooms in the house, and total number of family members are positively correlated with the energy consumption of the family and also they are statistically significant at 1 per cent level of significance. Moreover, it can be interpreted that the total income of the family and number of rooms in the house are highly correlated by $75 \%$ and $85 \%$ respectively with the level of energy consumption and the size of the family is less correlated by $28 \%$ only with the energy consumption level. All other values show the inter - relationship between the variables. To check the statistical relationship between the level of energy consumption and the type of family, location of the respondent, and energy conservation attitude, the statistical tool Chi-Square test was used. For this purpose, the quantitative data energy consumption was recorded into categorical data by classifying as low energy consumer, medium, and high energy consumer. Those who consume less than or equal to 100 units are called low energy consumers. Further, it has been divided as a medium level energy consumer and High-level energy consumer by the range101 500 units and above, respectively. The relationship between the levels of energy consumption and other characteristics of the household mentioned above is discussed in the following Table 11.

Table 11 Chi - Square Test Relationship between Type of Family and Electricity Consumption

\begin{tabular}{|c|c|c|c|c|}
\hline \multicolumn{5}{|c|}{ Type of Family } \\
\hline $\begin{array}{c}\text { Electricity } \\
\text { Consumption }\end{array}$ & $\begin{array}{c}\text { Joint } \\
\text { Family }\end{array}$ & $\begin{array}{c}\text { Nuclear } \\
\text { Family }\end{array}$ & Total & $\begin{array}{c}\text { Chi- } \\
\text { square } \\
\text { Value }\end{array}$ \\
\hline $\begin{array}{c}\text { Low Energy } \\
\text { Consumers }\end{array}$ & 2 & 93 & 95 & \\
\hline $\begin{array}{c}\text { Medium } \\
\text { level Energy } \\
\text { Consumers }\end{array}$ & 63 & 263 & 326 & $20.678^{* *}$ \\
\hline $\begin{array}{c}\text { High level } \\
\text { Energy } \\
\text { Consumers }\end{array}$ & 9 & 20 & 29 & \\
\hline Total & $\mathbf{7 4}$ & $\mathbf{3 7 6}$ & $\mathbf{4 5 0}$ & \\
\hline
\end{tabular}

**Significant at $1 \%$ level of significance.

Table 11 explains that the majority of the sample respondents, i.e., 326 respondents out of 450 , were medium level energy consumers, i.e., consuming $101-500$ units per two months. In this, 63 respondents belong to the joint family system, and the 263 respondents belong to the nuclear family system. While the high level of energy consumers was taken into account, majority of the respondents belong to the nuclear family system as they are using high power-consuming home appliances like Air Conditioner, Washing machine, Refrigerator, etc.,

The Chi-Square value 20.678 shows that there is a statistical relationship between electricity consumption and the type of family. Also, it has emerged as statistically significant at $1 \%$ level of significance.

\section{Findings}

- Out of the total 450 respondents, 35, 140, 202, and 73 live in huts, tiled houses, concrete houses, and storied houses, respectively. Out of 300 rural respondents, 23 (7.67 percent), 112 (37.33 percent), 126 (42.00 percent), and 39 (13.00 percent) live in huts, tiled houses, concrete houses, and storied houses respectively. Out 
of 150 urban respondents, 12 (8.00 percent), 28 (18,67 percent), 76 (50.67 percent), and 34 (22.67 percent) live in huts, tiled houses, concrete houses, and storied houses respectively. These data confirm that a majority of the respondents have concrete houses. This may be due to the free housing schemes of the Central and State Governments like Indira Awas Yojana Scheme (IAYS) and Chief Minister's Solar Powered Green House Scheme (CMSPGH).

- Out of the total 450 respondents, 362 live in owned houses, and 88 in a rented house. Out of 300 rural respondents, 246 ( 82 percent) live in owned houses and the remaining 54 (18 percent) in a rented house. Out of 150 urban respondents, 116 (77.33 percent) live in owned houses and the remaining 34 (22.67 percent) in a rented house. It shows that a majority of the rural, as well as urban respondents, possess their own houses. This is also due to free housing schemes by the governments.

- Out of the total 450 respondents $71,160,64,70$, 61 , and 24 are government employees, private employees, agricultural laborers, businessmen, contract workers, and other workers, respectively. Out of 300 rural respondents, 37 (12. 33 per cent), 100 (33.33 per cent), 56 (18.67 percent), 50 (16.67), 12 (14.00 percent) and 15 (5.00 percent) are government employees, private employees, agricultural labourers, businessmen, contract workers and other workers respectively. Out of 150 urban respondents, 34 (22.67 percent), 60 (40.00 per cent), 8 (5.33 per cent), 20 (13.33 per cent), 19 (12.67 percent) and 9 (6.00 percent) are government employees, private employees, agricultural labourers, businessmen, contract workers and other workers respectively.

- Out of 300 rural families, 66 (22.00 percent) belong to the annual family income below Rs.15, 000, and 167 (55.67 percent) come under the income range of Rs.15, 001 to Rs.30, 000. About 50 (16.67 percent) belong to the income range between Rs. 30,001, and Rs. 45,000. Remaining 11 (3.67 percent) and 6 (2.00 percent) fall under the income range of Rs. 45,001 to Rs. 60,000 and above Rs. 60,000 . Out of 150 urban families, 30 (20.00 percent) have an annual income of less than Rs. 15,000, while 65 (43.33 percent), 26
(17.33 percent), 12 (8.00 percent), and 17 (11.33 percent) families have an annual income between Rs. 15,001, and Rs. 30,000, Rs. 30,001, and Rs. 45,000, Rs. 45,001 and Rs.60,000 and above Rs.60,000.

- Out of 300 rural families, 200 (66.67 percent) have 3 to 6 members, and the families below three members are 54 (18.00 percent). About 46 (15.33 percent) families have above six members. Out of 150 urban families, 119 (79.33 percent) have 3 to 6 members, and the families below three members are 25 (16.67 percent). The families with more than six members are insignificant, i.e., 6 (4.00 percent). From the Table, we understand that both in rural and urban areas, a majority of 319 families have 3 to 6 members.

- Out of 300 households, 30 (10. 00 percent) use incandescent lamps and tube lights, CFL, and LED lamps are used by 190 (63.33 percent), 50 (16.67 percent), and 30 (10.00 percent) households respectively. In urban areas, incandescent lamps, tube lights, CFL, and LED lamps are used by 12 (8.00 percent), 60 (40.00 percent), 34 (22.67 percent), and 44 (29.33 percent) households respectively. Hence, it is observed that even though the CFL and LED lamps are introduced, a majority of the households in both rural and urban areas still use tube lights.

- Out of 300 rural households, the table fans and ceiling fans are used by 254 (84.67 percent) and 272 (90.67 percent) households respectively, whereas in urban areas, out of 150 households, it is 130 (86.67 percent) and 138 (92.00 percent) households respectively. The T.Vs. are used by 281(93.67 percent) rural households, and it is 143 (95.33 percent) for urban households. The tape recorders are used by 33 (11.00 percent) rural households, while in urban areas, it is 17 (11.33). The mixies are used by 236 (78.67 percent) and 137 (91.33 percent) rural households and urban households, respectively. The grinders are used by 166 (55.33 percent) rural households and 108 (72.00 percent) urban households. The refrigerators and air conditioners are used by 68 (22.67 percent) and 14 (4.67 percent) rural households respectively, and urban households it is 66 (44.00 percent) and 37 (24.67 percent), respectively. About 25 (8.33 percent) and 69 
(23.00 percent) rural households used washing machines and iron boxes respectively, whereas, for urban households, it is 40 (26.67 percent) and 64 (42.67 percent), respectively. The heaters and electric stoves are used by 12 (4.00 percent) and 37 (12.33 percent) rural households, respectively, while it is 21 (14.00 percent) and 23 (15.33 percent) respectively for urban households. The computers are used only by 6 (2.00 percent) rural households, but in urban areas, 10 (6.67 percent) households used computers. The lap tops are used by 67 ( 22.33 percent) rural households, but in urban areas, 54 (36.00 percent) households used lap tops. The motor pumps and mobile phones are used by 35 (11.67 percent) and 283 (94.33 percent) by rural households, respectively, and 53 (35.33 percent) and 146 (97.33 percent) by urban households respectively. In rural households, the UPSs and exhaust fans are used by 40 (13.33 percent) and 15 (5.00 percent) respondents, respectively, whereas it is 33 (22.00 percent) each for urban households. The table indicates that a large number of households have fans, TVs., mixies, and grinders. This is due to the priceless distribution of fans, T.Vs., mixies, and grinders by the State government.

- It is found that he household Characteristics such as the total income of the family, Number of rooms in the house, and the total number of family members are positively correlated with the energy consumption of the family, and also they are Statistically Significant at 1\% level of Significance.

- It is found that there is a Statistical relationship between electricity consumption and the type of family by using the chi-square test. Also, it has emerged as statistically significant at a $1 \%$ level of Significance.

\section{Suggestions}

- It is observed in the study that 141 (47.00 percent) rural households and 45 (30 percent) urban households still use the traditional energy systems like kerosene and fire wood and agricultural residues for cooking as their main source of energy. Therefore, mass awareness should be created about the use of modern energy-efficient technologies by replacing the existing old inefficient equipment. Further, these modern energy-efficient technologies should also be made available to rural households.

- About 294 (98.01 percent) of the households in rural areas and 133 (88.67 percent) in urban areas live below the poverty line. Hence, the policy makers should provide small credit to the households to help them to meet the cost of adoption of energy-saving household equipment.

- To develop sustainable energy, the study recommended conducting extension programs to enhance the respondents in the study area to adopt fire wood substitutes. Hence, the government should encourage the people in the study area to plant tree saplings around the residence.

- The day light should be used to save a significant amount of energy during a certain season in a year. In summer, when the Sun rises earlier, the number of useful hours of the day light also increases. Due to this, most of the daily household activities should be finished with daylight, and hence they do not use artificial light. This will result in the saving of fuel and electricity.

- The Government should motivate people to use bio-gas and smokeless Chula.

- Apart from other funds allotted to local bodies, the government should come forward to sanction more funds to panchayat authorities to install common major solar energy panels, which will generate surplus energy than required by the village.

- Instead of concrete roofing, it is mandatory to lay solar panel roofing in the houses to be constructed in the study area, so that the plan approval will be provided to construct a new house.

- In Out of 300 rural households, 220 (73.33 percent) and out of 150 urban households, 72 (48.00 percent) still use traditional appliances like incandescent lamps and tube lights. Hence, awareness should be created through mass media to use energy-efficient household appliances like CFL, LED bulbs, and LCD televisions, which are not only energy-efficient but also environment friendly.

- It is observed from the study that the main reason for more electricity consumption in rural and urban households in the study area is the distribution of free goods like T.V., grinder, and 
mixie by the government. Hence, it is suggested to stop the supply of free goods. This will not only conserve energy but also avoid laziness among the respondents and force them to engage in economic activities to run their families, which will increase the per capita income of the family and the national income.

- The Bureau of Energy Efficiency (BEE) has introduced a new star rating methodology for air conditioners manufactured and sold in India on 1st January 2018, which is called the Indian Seasonal Energy Efficient Ratio (ISEER). This star rating is also extended to refrigerators and washing machines. The star rating is a measure of the energy efficiency of an appliance. Usually, the star labels are fixed on the heavy electrical home appliances like air conditioners, refrigerators, and washing machines. The higher the rating, the lower is the energy consumption. Even though the prices of star rated commodities are high, the price to be paid for electricity will be low for a long period in the future (i.e., the life time of the product), when compared to the nonstar rated commodities. Hence, the respondents in the study area should be motivated to purchase the star rated commodities to conserve energy. Further, the intervention of the government is the need of the hour to propose an energy-efficient plan by adopting compulsory production and consumption of star rating products. It will save energy and cost.

- Above all, various Departments of the State and Central Governments and voluntary organizations should organize seminars, conferences, symposia, workshops, street plays, and other such activities at the village level to raise public awareness on energy conservation. Further, adequate training should be provided to households in the study area to adopt the efficient use of energy.

\section{References}

Amutha, D. Environmental Economics, Mangalam Publishers and Distributers, New Delhi, 2016. Anderson, V. Energy Efficiency Policies, Routledge, London, 1993.

Biswas and Madhumitha. Environmental Economics, Mittal Publications, New Delhi, 2007.

Bodris, JOM. Energy Options, Real Economics, and the Solar Hydrogen System, Taylor \& Francis Ltd., London, 1980.

Bose, D., Ganesan, S. and Ashok Kumar, G. "Environmental Pollution by MSMEs with Special Reference to Brick Units in Srivilliputthur Taluk - A Micro Level Study." Micro, Small and Medium Enterprises (MSME) Problems, edited by Madasamy, V., M.S.K. Publications, Salem, 2012.

Ganesan, S., Bose, D. and Ashok Kumar, G. "Household Electricity Savings and $\mathrm{CO} 2$ Emission Reduction Possibility by Replacing Incandescent Lamps and Tube Lights: A Case Analysis." International Journal of Ecology and Development, vol. 25, no. 2, 2013, pp. 114-125.

Kuldeep, K. and Amandeep, K. "Electricity Consumption and Economic Development- Interrelationship in Punjab." Journal of Economic Development, vol. xxxvi, no. 2, 2000, pp. 312-327.

Murugan, M. "An Analysis of Rural Households Energy Consumption in Kanyakumari District of Tamil Nadu." International Journal of Multidisciplinary Research, vol. 1, no. 7, 2011, pp. 130-139.

Narasimha Murthy, KV, Sumithra, GD and Reddy, AKN. "End - Uses of Electricity in Households of Karnataka State, India." Energy for Sustainable Development, vol. V, no. 3, 2001, pp. 81-94.

\section{Author Details}

K.Ramabose, Ph.D. Research Scholar in Economics, Ayya Nadar Janaki Ammal College (A), Sivakasi, Tamil Nadu, India, Email ID: ramabose10687@gmail.com.

Dr.S.Ganesan, Associate Professor in Economics, Ayya Nadar Janaki Ammal College (A), Sivakasi, Tamil Nadu, India. 